\title{
Pharmaceutical Analysis of Guduchi-Bhadramustadi Ghanvati: An Ayurvedic Formulation for Dyslipidemia
}

\author{
Research Article
}

\section{Lokesh Kumar $^{*}$, Prakash Kumbhar², Janhavi Patharkar³}

1. PG Scholar, 2. Associate Professor, 3. Assistant Professor, Department of Kayachikitsa, Parul Institute of Ayurveda, Parul University, Vadodara, Gujarat, India.

\begin{abstract}
Ayurveda a science life which deals the maintenance of health and treatment for the diseases manifested in the human body. In Ayurveda many herbal and herbo-mineral formulations have been explained for disease treatment. Guduchi-Bhadramustadi yoga is herbal formulation explained in classical which consists of five herbal medicines and it has been converted in to Ghanavati form by following the sop in GMP certified pharmacy. It is a classical preparation used in the management of Kapha Dosha Vikaras by practitioners. Material \& Methods: The present study was aimed to recognize the constituents of Guduchi-Badraustadi Ghanavati by using physico-chemical parameters, Qualitative analysis and Chromatography (HPTLC). Conclusion: This study will be useful for standardization of Guduchi-Badramustadi Ghanavati and for the preparation of the monography of this formulation for the Ayurvedic Formulary of India (AFI).
\end{abstract}

Key Words: Guduchi-Bhadramustadi Ghanvati, Dyslipidemia, HPTLC.

\section{Introduction}

Ayurveda is science which deals with diseases management and promotion of health. Many ayurvedic formulation have been explained in classics which includes herbal, herbo-mineral and mineral. In present era herbal formulation are widely used and promoting globally for the treatment of many diseases(1). Considering these points, the Standardization of herbal formulations is crucial for the assessment of drug quality. It is also important to know the active principles and its chemical constituents of the herbal formulation. The acceptability and safety of the drug depends on the quality the formulation(2). So, it is important to do quality assessment of the formulation. One of the major problems faced by Ayurveda physicians is the lack of unique quality control parameters for herbal medicines and their formulations. In India, the Department of AYUSH Government of India has launched a central scheme to develop standard operating procedures for the manufacturing process in order to develop pharmacopoeial standards for Ayurvedic preparations(3). In present era formulation needs to be standardized so it can get acceptance globally. This formulation has been explained in classics for the mangement of sthoulya(4). In this present study, Guduchi- Badramustradi Ghanavati was prepared

* Corresponding Author:

\section{Lokesh Kumar}

PG Scholar,

Department of Kayachikitsa,

Parul Institute of Ayurveda, Parul University,

Vadodara, Gujarat, India.

Email Id: 1oki.gaur32@gmail.com following the standard operating procedures in GMP certified pharmacy. This formulation is commonly used in clinical practice for the treatment of Rasa pradoshaja diseases. Since the therapeutic values and efficacy of the formulation depend on the several aspects, the present study has taken up for pharmaceutical analysis.

The analytical study of the Ghanavati was performed with following parameters: Organoleptic parameters (Appearance, color, odor, taste), physiochemical parameters (Loss on drying, Total ash, Acid insoluble ash, Water soluble extract, Alcohol soluble extract, $\mathrm{pH}$, Uniformity of weight, Friability, Hardness, Disintegration time), qualitative and HPTLC.

\section{Aims and Objectives}

- Identification and authentication of raw drugs used for Guduchi Badamustadi Ghanavati.

- Preparation of Guduchi Badramustadi Ghanavati at GMP certified pharmacy.

- Physicochemical, phytochemical and HPTLC analysis of Guduchi Badamustadi Ghanavati.

\section{Materials and Methods}

\section{Collection Plant Material}

Musta (Cyperus Rotundus.Linn), Guduchi (Tinospora Cordifolia. Thumb), Amalaki (Emblica officinalis. Gaertn), Vibheetaki (Terminalia Bellerica. Gaertn), Haritaki (Terminalia Chebula. Retz) were purchased from authenticated resources at Vadodara.

\section{Identification and Authentication of Raw Drugs}

Raw drugs identification and authentication was done by the Department of Dravya guna, Parul Institute of Ayurveda, Parul University, Vadodara. 
Method of preparation Guduchi-Bhadramusthadi Ghanvati

The ingredients of Guduchi Badramustadi Ghanavati (Table 1) were taken in equal quantity and converted into coarse powder. The coarse powder was well mixed in a mass mixer until a homogenous mixture was obtained. The Kashaya was prepared by obtained mixture and transformed into Ghana according to the guidelines given in Sharangdhar Samhita (5). Prepared Ghana was kept in a hot oven for 3 days until it was completely dried. The dried Ghana was collected from hot oven after complete drying and table of $500 \mathrm{mg}$ were prepared by using tablet pressing machine.

Table 1: Showing Ingredients of Guduchi-Bhadramusthadi Ghanavati

\begin{tabular}{|l|l|l|l|l|}
\hline $\begin{array}{l}\text { Sr. } \\
\text { No }\end{array}$ & $\begin{array}{l}\text { Name of } \\
\text { Drug }\end{array}$ & Botanical name & Family & $\begin{array}{l}\text { Part } \\
\text { used }\end{array}$ \\
\hline 1 & Amalaki & $\begin{array}{l}\text { Emblica } \\
\text { officinalis Linn }\end{array}$ & $\begin{array}{l}\text { Phyllant } \\
\text { haceae }\end{array}$ & Fruit \\
\hline 2 & Haritaki & $\begin{array}{l}\text { Terminalia } \\
\text { Chebula Retz }\end{array}$ & $\begin{array}{l}\text { Combre } \\
\text { taceae }\end{array}$ & Fruit \\
\hline 3 & Vibheetaki & $\begin{array}{l}\text { Terminalia } \\
\text { bellerica } \\
\text { Gaertn }\end{array}$ & $\begin{array}{l}\text { Combre } \\
\text { taceae }\end{array}$ & Fruit \\
\hline 4 & Guduci & $\begin{array}{l}\text { Tinospora } \\
\text { cordifolia Thunb }\end{array}$ & $\begin{array}{l}\text { Menispe } \\
\text { rmaceae }\end{array}$ & Stem \\
\hline 5 & Musta & $\begin{array}{l}\text { Cyperus } \\
\text { rotundus Linn }\end{array}$ & $\begin{array}{l}\text { Cyperac } \\
\text { eae }\end{array}$ & Rhizome \\
\hline
\end{tabular}

\section{Methods of evaluation of Guduchi-Badramustadi Ghanavati}

Guduchi-Badramustadi Ghanavati was analyzed by using standard qualitative and quantitative parameters. All the procedures were conducted at G.M.P certified Parul Ayurvedic Pharmacy Laboratory, Vadodara.

\section{Physico-Chemical Analysis}

It includes parameters like colour, taste, $\mathrm{pH}$, Loss on Drying (6), total ash (7), acid insoluble ash(8), alcohol soluble extractive (9), water soluble extractive (10) uniformity of weight (10), disintegration time(11) friability test (12), \& hardness (13).

\section{Qualitative analysis}

The qualitative analysis (14) of Guduchi -Bhadramustha Ghanvati was done for Glycoside Sugar, Alkaloids, Tannins, Flavonoids, Gallic acid, Ascorbic Acid, Saponin, Starch.

\section{Chromatography}

HPTLC (high-performance thin layer chromatography) is a sophisticated form of TLC, which works same principles as that TLC i.e., the principle of separation is adsorption. high performance thin layer chromatography (15) gives much greater resolution and separation of components than normal TLC. it uses chromatographic stationary phases with excellent separation efficiency and employs state of the art instrumentation for all steps in the procedure. Method and other procedures followed for HPTLC of Guduchi Badramustadi Ghanavati discussed below.

\section{Results and Discussion}

The formulation Guduchi-Badramustadi Ghanavati was prepared following standard operating procedures in GMP certified pharmacy and was subjected for qualitative and quantitative analysis. The pharmaceutical analysis results were discussed below.

\section{Organoleptic evaluation}

The organoleptic parameters are the basic criteria for selecting raw ingredients and confirming the quality of the finished formulation. The texture of the finished formulation was found to be smooth, indicating surface uniformity without cracks. The color was black, the taste was pungent and the smell was slightly aromatic and characteristic due to the special properties of the ingredients used. Table 2

\section{Table 2: Organoleptic Characteristics of Guduchi-Bhadramusthadi Ghanavati}

\begin{tabular}{c|c|c|} 
SI. No. & Characters & Observed \\
\hline 1 & Color & Black \\
\hline 2 & Odor & Slightly Aromatic \\
\hline 3 & Taste & Pungent \\
\hline
\end{tabular}

\section{Physico-Chemical Analysis of Guduchi -Bhadramustadi Ghanavati \\ Loss on drying}

Drying between samples indicates that the samples are devoid of excess water content and that there is no microbial overgrowth or insect infestation. In the sample of Guduchi-Bhadramustadi Ghanavati loss of drying was found to be $2.56 \%$, which means that the samples have a good shelf-life and will not decay when stored.

\section{Total ash and acid insoluble ash}

It provide information on contamination, substitution, adulteration. Low total ash and acid insoluble ash means low levels of inorganic matter and Contents of silica. In this sample, the value of GuduchiBhadramustadi Ghanvati ash was $1.07 \%$, which was slightly higher and may be due to the presence of fibers and sclereids in the ingredients.

\section{Water and Alcohol soluble extracts}

Water soluble extract and Alcohol soluble extract were 81 per cent and 3.86 per cent respectively in the sample of Guduchi-Bhadramustadi Ghanavati. The high solubility of the sample in water indicates that the drug is best suited for extraction with water or water-based preparations. The negligible presence of Volatile oils is also in favor of thermal extraction with water.

\section{pH}

The $\mathrm{pH}$ is measured to detect the acidity or alkalinity of the aqueous solution of the drug, which helps to understand the pharmacological basis of drug absorption and metabolism. In this sample, GuduchiBhadramustadi Ghanavati $\mathrm{pH}$ was 4.9 percent, therefore, it is clear that the drug tested was acidic in nature. 


\section{Uniformity of weight}

It helps to distribute drugs and to fix the quantity of drugs. The average weight of the present sample of Guduchi-Bhadramustadi Ghanavati was 510 mg, which denotes the uniformity of the weight in relation to the planned weight of each Ghanavati i.e., $500 \mathrm{mg}$.

\section{Disintegration time}

The disintegration time of this sample was reported to be 36 minutes. Disintegration time of the tablet is an important criterion for quality assessment, as it provides important clues as to the bioavailability of the contents of the tablet. In further research on the same trial drug, comparative criteria for assessing the quality of the formulation have become essential.

\section{Hardness and friability}

The hardness of the tablet should not be less than $3 \mathrm{~kg} / \mathrm{cm} 2$ whereas the friability is at an ideal level of $1 \%$. The Guduchi-Bhadramustadi Ghanavati sample had a hardness of $5.2 \mathrm{~kg} / \mathrm{cm} 2$ and was found to have a friability of 0.45 per cent, therefore both values were within the required range indicating the durability of the finished formulation. TABLE 3.

\section{Table 3: Physico-Chemical Analysis of Guduchi-Bhadramustadi Ghanavati}

\begin{tabular}{l|l|l|} 
Sr. No & Parameter & Value \\
\hline 1 & Loss on drying at $105^{\circ} \mathrm{C}(\% \mathrm{w} / \mathrm{w})$ & 2.56 \\
2 & Total Ash Value $(\% \mathrm{w} / \mathrm{w})$ & 1.07 \\
3 & Acid Insoluble Ash $(\% \mathrm{w} / \mathrm{w})$ & 0.87 \\
4 & Water soluble extractive $(\% \mathrm{w} / \mathrm{w})$ & 81 \\
5 & Alcohol soluble extractive $(\% \mathrm{w} / \mathrm{w})$ & 3.86 \\
6 & $\mathrm{pH}(5 \%$ Aqueous) & 4.9 \\
7 & Hardness $\left(\mathrm{Kg} / \mathrm{cm}^{2}\right)$ & 5.2 \\
8 & Disintegration time (minutes) & 36 \\
\hline 9 & Weight variation & \\
& Average weight $(\% \mathrm{w} / \mathrm{w})$ & $510 \mathrm{mg}$ \\
& Highest weight $(\% \mathrm{w} / \mathrm{w})$ & 3.34 \\
\hline & Lowest weight $(\% \mathrm{w} / \mathrm{w})$ & 1.45 \\
\hline 10 & Friability Test $(\% \mathrm{w} / \mathrm{w})$ & 0.45
\end{tabular}

Qualitative analysis: Guduchi-Bhadramustadi

Ghanavati was subjected for the qualitative analysis to identify the active principles of the formulation which shows presence of alkaloids, tannin, saponin, ascorbic acid and glycoside sugar as shown in TABLE 4.

Table 4: Showing Qualitative Analysis of Guduchi-Bhadramustadi Ghanavati

\begin{tabular}{|l|l|l|}
\hline SR. NO. & Solvent & $\begin{array}{l}\text { Present }(+) / \\
\text { Absent }(-)\end{array}$ \\
\hline 1 & Glycoside Sugar & + \\
2 & Alkaloids & + \\
\hline 3 & Tannin & + \\
\hline 4 & Saponin & + \\
\hline 5 & Ascorbic Acid & + \\
\hline 6 & Gallic Acid & + \\
\hline 7 & Starch & + \\
\hline 8 & Triterpenoid & - \\
\hline
\end{tabular}

\section{Chromatography}

It was carried out at Vasu Research Centre, Vadodara. HPTLC fingerprinting report was done to analyze the finished formulation GuduchiBhadramustadi Ghanvati.

\section{High-Performance Thin Layer Chromatographic Study}

Prepare the sample: Weigh in a conical flask: Weigh in two glass $2 \mathrm{~g}$ of the sample, then apply $20 \mathrm{ml}$ of methanol. 1 hour of reflux in a warm bath When the timer goes off, use Whatman filter paper No. 1 to filter. Place the filter in an evaporating dish and evaporate it until it is fully dry. $5 \mathrm{~mL}$ methanol to reconstitute the sample as a result, you will use the test solution for HPTLC fingerprinting. Spray reagent (Anisaldehyde Sulphuric acid reagent) preparation: A mixture of 0.5 $\mathrm{mL}$ anisaldehyde, $10 \mathrm{~mL}$ glacial acetic acid, $85 \mathrm{~mL}$ methanol, and $5 \mathrm{~mL}$ is prepared.

Chromatographic condition: HPTLC chromatographic condition details have been mentioned in Table no.5.

\section{Table 5: Showing Chromatographic Conditions of Guduchi-Bhadramusthadi Ghanavati}

\section{Chromatographic Conditions:}

\begin{tabular}{|c|c|}
\hline Application Mode & $\begin{array}{l}\text { CAMAG Linomat } 5 \text { - } \\
\text { Applicator }\end{array}$ \\
\hline Filtering System & Whatman filter paper No. 1 \\
\hline Stationary phase & $\begin{array}{l}\text { MERCK - TLC / HTPLC } \\
\text { Silica gel } 60 \mathrm{~F}_{254} \text { on } \\
\text { Aluminium } \\
\text { Sheets }\end{array}$ \\
\hline $\begin{array}{l}\text { Application (Y axis) } \\
\text { Starting Position }\end{array}$ & $10 \mathrm{~mm}$ \\
\hline $\begin{array}{l}\text { Development End } \\
\text { Position }\end{array}$ & $80 \mathrm{~mm}$ from plate base \\
\hline $\begin{array}{l}\text { Sample Application } \\
\text { Volume }\end{array}$ & $2.0 \mu \mathrm{L}$ \\
\hline Development Mode & $\begin{array}{l}\text { CAMAG TLC Twin } \\
\text { Trough Chamber }\end{array}$ \\
\hline Chamber Saturation Time & 30 minutes \\
\hline Mobile Phase (MP) & $\begin{array}{l}\text { Toluene: Ethyl Acetate: } \\
\text { Formic Acid }(7: 3: 1)\end{array}$ \\
\hline Visualization & $\begin{array}{l}\text { @ } 254 \mathrm{~nm} \text {, @ } 366 \mathrm{~nm} \text { and } \\
\text { @ } 540 \mathrm{~nm} \text { (after } \\
\text { derivatization) }\end{array}$ \\
\hline Spray Reagent & $\begin{array}{l}\text { Anisaldehyde Sulphuric } \\
\text { Acid reagent }\end{array}$ \\
\hline Derivatization mode & $\begin{array}{l}\text { CAMAG - Dip tank for } \\
\text { about } 1 \text { min }\end{array}$ \\
\hline $\begin{array}{l}\text { Drying Mode, Temp. \& } \\
\text { Time }\end{array}$ & $\begin{array}{l}\text { TLC Plate Heater } \\
\text { Preheated at } 100 \pm 5^{\circ} \mathrm{C} \text { for } 3 \\
\text { minutes }\end{array}$ \\
\hline
\end{tabular}

\section{HPTLC details at different $\mathrm{Rf}$}

After derivatization, plate was examined for appearance of different bands at different $R_{f}$. and following were the findings: 
Details of HPTLC profile of all tracks@254

$\mathrm{nm}$ : Under the $254 \mathrm{~nm}$ wavelength-Track -T1 of Guduchi-Bhadramustadi Ghanvati, 7 spots were detected and starts with respect to retardation factor $0.27,0.39,0.45,0.54,0.59,0.64$ and 0.78 .

Details of HPTLC profile of all tracks at 366 $\mathrm{nm}$. Under the $366 \mathrm{~nm}$ wavelength-Track -T1 of Guduchi-Bhadramustadi Ghanvati , 6 spots were detected and starts with respect to retardation factor $0.19,0.32,0.59,0.64,0.78$ and 0.81 .

Details of HPTLC profile of all tracks at 540 $\mathrm{nm}$ : Under the $540 \mathrm{~nm}$ wavelength-Track -T1 of Guduchi-Bhadramustadi Ghanvati, 5 spots were detected and starts with respect to retardation factor $0.27,0.39,0.45,0.63$ and 0.78 .

HPTLC, which was generated@254 nm,@ $366 \mathrm{~nm}$ and @ $450 \mathrm{~nm}$ after the derivatization, revealed that the presence of 7 spots, 6 spots and 5 spots at each wavelength respectively. Thus, the formulation is rich in phytoconstituents.

\section{Conclusion}

The Ayurvedic system of medicine is increasingly being relied on for various health issues, particularly lifestyle diseases. The ingredients have been pharmacognostically identified and authenticated and used for preparation. Any plant or formulation used medicinally requires a detailed study prior to its use, as the therapeutic efficacy depends on the quality of the ingredients used for the preparation of the medicinal product. The prepared drug, Guduchi-Badramustadi Ghanavati was pharmacologically subjected for physicochemical analysis, qualitative and HPTLC. The ingredients of Guduchi-Badramustadi Ghanavati are guduchi, musta, amalaki, haritaki and vibhitaki and it is an herbal formulation.

In this study, Guduchi-Bhadramustadi Ghanavati was prepared in accordance with the classical references and following standard operating procedures at GMP certified pharmacy. Raw drugs were identified and authenticated prior to use for preparation. The drug was pharmacologically subjected to physicochemical analysis, qualitative and HPTLC analysis. The groundwork requirements for standardization of Guduchi-Bhadramustadi Ghanavati have been attempted in this study. In the future, this study will help to standardize Guduchi-Bhadramustadi Ghanavati and to prepare the monograph of this for Ayurvedic Formula of India (AFI).

\section{References}

1. WHO (2004). WHO Guidelines on Safety Monitoring of Herbal Medicines in Pharmacovigilance Systems. Geneva, Switzerland: World Health Organization.

2. Arun Rasheed, A Review on standardization of herbal formulations, Inter. J. of Phytotherapy / Vol. 2 / Issue 2 / 2012 / 74-88.

3. Kalyani Jadhav, Standardization of Ayurvedic Drugs, Satyanveshnama 2007.

4. Bhrahmanand Tripathi, Charak Samhita, Varanasi, Chaukhamba Surbharati Prakashan:2013, Vol-I, Pg, No.404

5. Sarnadharacarya \& Bramhanda Tripati, Sharangdhar Samhita , Varanasi, Madhyam Kanda, Kwathadi Kalpana ; Chaukhambha Surbharti Prakashan, 2016, Pg No. 90

6. Sanmugarajah V, Thabrew I, Sivapalan SR. Phyto, physicochemical standardization of medicinal plant Enicostemma littorale, blume. IOSR J Pharm 2013; 3:53.

7. Chaudhari RK, Girase NO. Determination of soluble extractives and physicochemical studies of bark of Sesbania sesban (L) Merr. J Chem 2015; 7:658.

8. The Ayurvedic Pharmacopeia of India. Government of India. Part I. $1^{\text {st }}$ ed. Vol. II. Apx-2. New Delhi: Controller of Publications; 1999. p. 191.

9. The Ayurvedic Pharmacopeia of India. Government of India. Part I. $1^{\text {st }}$ ed. Vol. II. Apx-2. New Delhi: Controller of Publications; 1999. p. 190.

10. Available from: https://www.jstor.org/ stable/ 2347313? seq=1\#page_scan_tab_contents. [Last accessed on 2017 May 08].

11. Available from: http://www.plimism.nic.in/ Protocol_For_Testing.pdf. [Last accessed on 2017 May 08].

12. Mathur N, Kumar R. Evalution of quality Control Parameters on various brands of paracetamol tablet formulation. World J Pharm Pharm Sci 2015; 4:982.

13. Lachman L, Lieberman HA, Kanig JL. The Theory and Practice of Industrial Pharmacy. Special Indian Edition. Bombay: Varghese Publishing House; 2009. p. 299.

14. Pulok K. Mukherjee, Quality Control and Evaluation of Herbal Drugs, Evaluating Natural Products and Traditional Medicine, first edition, Elsevier Science, 2019, pg 212-217.

15. Hildebert Wagner \& Sabine Bladt, Plant Drug Analysis: A Thin Layer Chromatograph Atlas, second edition, Berlin, Springer, 2009, pg: 355-357. 